\title{
Management Earnings Forecast And Earnings Management: Does Prior-Period Forecast Accuracy Play A Role?
}

\author{
Jing-Wen Yang, California State University-East Bay, USA
}

\begin{abstract}
This study aims at examining 1) whether the market reacts differently in response to the same news, but based on different levels of accuracy from prior earnings forecasts; 2) whether managers tend to maintain or change their reputations for being optimistic or pessimistic in their forecasts; and 3) whether managers manage current earnings numbers in order to maintain or change their reputations for optimistic or pessimistic forecasting. Based on t-tests and the Wilcoxon rank-signed test, it was discovered that the market reacts more positively (negatively) on good (bad) news with a pessimistic (optimistic) prior earnings forecast. Further, when a firm is pessimistic in its forecasts, it tends to stay pessimistic, but when a firm has a reputation for optimistic forecasts, it does not appear to change that reputation. A firm with an optimistic prior forecast is more likely to manage earnings upwards by influencing one of the following: increasing total accruals, boosting inventory levels, or lowering discretionary expenses.
\end{abstract}

Keywords: Earnings Forecast; Earnings Management; Prior-Period Forecast Accuracy

\section{INTRODUCTION}

s it beneficial for a company manager to be pessimistic in his earnings forecasts and remain so?
Anecdotal evidence shows that management earnings forecast accuracy from prior periods influences
investors' perceptions about future earnings and impacts investors' confidence in current management
earnings forecasts (e.g., Williams, 1996; Hirst, Koonce and Miller, 2000; Rogers and Stocken, 2005). Other research
studies (e.g., Soffer, Thigarajan and Walther, 2000; Bail and Jiang, 2006) argue that management could use
pessimistic earnings forecasts to dampen analysts' expectations in order to avoid negative earnings surprises. It is
not yet clear, however, whether company management strives to remain pessimistic in its forecasts or to alter its
reputation for being optimistic in its forecasts if it has such a reputation.

One approach that a company manager can adopt to be seen as pessimistic in his forecasts is to manipulate current earnings numbers. Prior studies (e.g., Kasznik, 1999; Lobo and Zhou, 2001) have shown that given the management earnings forecast of the current period, management tends to manage earnings numbers to meet or beat that forecast. It is not clear, however, whether management is motivated to manage its current earnings numbers in order to continue to be seen as pessimistic in its forecasts or whether it tries to change its reputation for being optimistic in terms of forecasts. In addition, is there a higher incentive for a firm to manipulate its reputation if its prior forecast is optimistic? Therefore, the purposes of this paper are: 1) to reinvestigate whether the market reacts differently to earnings forecasts when prior forecast accuracies differ, 2) to examine whether managers tend to maintain or correct their reputations for making earnings forecasts, and 3) to explore whether managements are incented to manage their current earnings upward or downward given prior-period forecast errors?

Based on t-tests and Wilcoxon rank-signed tests, it was discovered that markets react more positively to good news when their prior forecasts were pessimistic and more negatively to bad news when prior forecasts were optimistic. The stock market appears to be fixed on a management's prior forecast accuracy and responds accordingly. 
Next examined was whether a firm with a pessimistic prior forecast tends to maintain its reputation for pessimism and whether a firm with an optimistic prior forecast tends to attempt to change its reputation. Based on the Pearson chi-squared test, it was discovered that if a firm was pessimistic in its forecasts in a prior year, it tends to remain so in the current year. However, there was no evidence that a firm with an optimistic prior forecast successfully changes its reputation; it was more likely to remain optimistic in its forecasts.

The third issue investigated was the approach a firm uses to maintain or change its reputation. The hypothesis was that a firm could manage its earnings through manipulating total accruals or influencing real activities. The two real activities examined in this study were: 1) increasing production in order to increase inventory levels and 2) decreasing discretionary expenses, such as research and development costs, advertising costs, or expenses related to sales and administration. An Ordinary Least Squared regression analysis was performed and it was discovered that a firm tends to manipulate earnings upwards when it was optimistic in its forecasts in the prior period. Such a firm could have tried to boost its current earnings numbers to change its reputation, but might have failed to achieve its goal.

A prior study by King, Pownall, and Waymire (1990) argues that, based on Ajinka and Gift's (1984) expectations-adjustment hypothesis, management's credibility affects investor reaction to management earnings forecasts. One aspect of credibility is prior-period forecast accuracy. This paper extends the expectations-adjustment hypothesis by examining whether management manipulates current earnings to remain accurate or, more particularly, to remain pessimistic, given the fact that market rewards prior pessimism and punishes prior optimism.

The results in studies by Williams (1996) and Rogers and Stocken (2005) indicate that managers' reputations from prior earnings forecasts could play a role in market reaction to current management earnings forecasts. Williams (1996) found that analysts take into account managers' reputations from prior earnings forecasts and revise their forecasts accordingly. The implication is that management establishes its reputation for forecasting through prior earnings forecasts. Rogers and Stocken (2005) showed that "for good news forecasts the market responds less positively to forecasts with higher predicted optimism and more positively to forecasts with higher predicted pessimism...for bad news forecasts, the results show an analogous relation." Based on these two prior findings, this study contributes to the literature by documenting a possible time-series trend in managers' earnings forecast behavior and a potential incentive for managers to manage earnings numbers.

The remainder of the paper examines whether market responses to management earnings forecasts differ based on different prior forecast accuracy, whether managers have a tendency to be pessimistic or optimistic in their forecasts, and whether managers manage earnings in order to maintain their forecasting reputations.

\section{PRIOR EARNINGS FORECASTS AND WHETHER THEY MATTER}

This section investigates whether the market takes into account accuracy from prior earnings forecasts and reacts to current earnings forecasts differently.

\section{Hypothesis Development}

An earnings forecast is one mechanism that management can use to communicate their beliefs to the public. Managers have incentives to bias the forecast, but, at the same time, they should keep in mind that their reputations build on the accuracy of their forecasts. Once their reputation is established, investors could react differently to the same type of news based on forecasts coming from managers with different reputations. If forecasts in the given year bring good news, market reaction could differ depending on whether managers were optimistic or pessimistic in their forecasts in the previous year. Market reaction to forecasts with bad news will also be similar. In other words, investors' perceptions on managers' words could be influenced from the managers' forecasts in the previous year. This leads to the following hypotheses stated in alternative forms:

H1a: Market reaction to a management forecast with good news will be more positive based on a pessimistic prior earnings forecast than on an optimistic prior earnings forecast. 
H1b: Market reaction to a management forecast with bad news will be more negative based on an optimistic prior earnings forecast than on a pessimistic prior earnings forecast.

\section{Model, Variable Definition, And Data Collection}

Accuracy of prior earnings forecasts is the characteristic on which this study focuses. Accuracy of a forecast depends on how well the forecast number approximates the earnings number issued subsequently. Therefore, accuracy of a forecast (FE) is defined as the difference between management's earnings forecast number and the actual earnings number, deflated by closing stock price one trading day prior to earnings forecast. Observations with a closing stock price smaller than $\$ 2$ were deleted in order to control for the problem of small denominators. A forecast is defined as pessimistic if FE is negative and optimistic if FE is positive.

If several forecasts were made in the prior year (t-1), only the last earnings forecast is used to calculate FE. Earnings forecasts made after fiscal year end were eliminated on the assumption that the market would be more likely to remember how well managers performed in their last forecast rather than in the first one.

Market reaction to a management earnings forecast issued in the current year (year $t$ ), based on FE in year $\mathrm{t}-1$, was checked. If several forecasts were made in the current year ( $\mathrm{t}$, only the first earnings forecast was kept. Market reaction is reflected in cumulative abnormal returns (CAR), which is the difference between the cumulative daily return and the size-decile-matched CRSP Value-Weighted Index return over the window that includes the day $($ day $=0)$ an earnings forecast was made and one day after its release. Since market response to a forecast with good news is typically different from a forecast with bad news, market response based on the content of the forecast was examined. The good news group and the bad news group were examined separately. If the current earnings forecast number (year $\mathrm{t}$ ) was above (below) prior actual earnings number (year $\mathrm{t}-1$ ), then the forecast is defined as releasing good (bad) news.

The Company Issued Guidance database generated by Thomson First Call was used to identify management earnings forecasts issued between years 1991 and 2010. Actual earnings data were drawn from the First Call database to be consistent with the earnings forecast numbers. Stock price and return data were collected from the CRSP database. After requesting data availability to calculate variables, the final number of the sample is $6,363(1,465)$ in the good (bad) news group for the test on accuracy.

\section{Empirical Results}

Table 1 presents descriptive statistics of forecast error, based on groups with different content. It also presents descriptive statistics of forecast credibility (CRED), which is defined as the absolute value of FE. A higher number of CRED represents a higher credibility. For earnings forecasts that convey good news, on average, they were optimistic in the previous year's forecast. On the other hand, for forecasts that announced bad news, on average, they were more pessimistic in the previous year. As for credibility, the group that forecasts good news in the current year tends to be less credible than the group that forecasts bad news in the current year.

Table 1: Descriptive Statistics Of Prior Forecast Error $\left(\mathrm{FE}_{\mathrm{it}-1}\right)$ And Prior Credibility $\left(\mathrm{CRED}_{\mathrm{it}-1}\right)$

\begin{tabular}{|c|c|c|c|c|c|c|}
\hline & No of Obs. & Mean & Standard Deviation & Q1 & Median & Q3 \\
\hline Prior Forecast Error $\left(\mathbf{F E}_{\text {it-1 }}\right)$ & & & & & & \\
\hline Good News Group & 6,711 & 0.0103 & 0.0406 & -0.0014 & 0 \\
\hline Bad News Group & 1,583 & -0.0445 & 0.3660 & -0.0046 & -0.0007 & 0.0172 \\
\hline Prior Credibility (CRED & it-1 $)$ & & & & & \\
\hline Good News Group & 6,711 & 0.0136 & 0.0396 & 0.0009 & 0.0032 & 0.0185 \\
\hline Bad News Group & 1,583 & 0.0533 & 0.3648 & 0.0011 & 0.0036 & 0.0102 \\
\hline
\end{tabular}

*Management forecasts above prior year earnings are defined as good news, while those below prior year earnings number are defined as bad news.

** Variable definitions:

$\mathrm{FE}_{\mathrm{it}-1}$ : Prior-year forecast error, which is the difference between the management earnings forecast and the actual earnings per share, deflated by the closing price one trading day before the announcement of earnings forecast, in year $\mathrm{t}-1$.

$\mathrm{CRED}_{\mathrm{it}-1}$ : Prior-year credibility of earnings forecast, which is the absolute value of the ratio (management earnings forecast actual earnings per share)/ closing price, in year $\mathrm{t}-1$. 
Table 2 shows results from a t-test on difference in mean and a Wilcoxon signed-rank test on difference in median. The results indicate that the market reacts significantly more positively to good news if managers were pessimistic in the past as opposed to the reaction if managers were optimistic in the past. The market also reacts significantly more negatively to bad news if managers were optimistic in the past as opposed to the reaction if managers were pessimistic in the past. Investors might have presumed that managers would continue to be pessimistic or optimistic in making forecasts and have chosen to respond to the same news differently based on their observations from the prior year's forecast.

Table 2: Comparison Of Cumulative Abnormal Returns $\left(\mathrm{CAR}_{\mathrm{it}}\right)$ Between Pessimistic And Optimistic Prior Forecasts In The Good News Group And The Bad News Group, Separately

\begin{tabular}{|c|c|c|c|c|c|}
\hline & $\begin{array}{c}\text { Number of } \\
\text { Observations }\end{array}$ & $\begin{array}{c}\text { Pessimistic Prior Forecast } \\
\left(\text { FE }_{\mathrm{it}-1} \leq \mathbf{0}\right) \\
\text { Mean } \\
\text { Median }\end{array}$ & $\begin{array}{c}\text { Optimistic Prior Forecast } \\
\left(\text { FE }_{\text {it-1 }}>0\right) \\
\text { Mean } \\
\text { Median }\end{array}$ & $\begin{array}{c}\text { Mean } \\
\text { Difference } \\
\text { (p-value) }\end{array}$ & $\begin{array}{c}\text { Median } \\
\text { Difference } \\
\text { (p-value) }\end{array}$ \\
\hline $\begin{array}{l}\text { Good News* } \\
\text { Group }\end{array}$ & 6,711 & $\begin{array}{l}0.0134 \\
0.0099 \\
\end{array}$ & $\begin{array}{l}0.0036 \\
0.0046\end{array}$ & $\begin{array}{c}0.0098 \\
(<0.0001)\end{array}$ & $\begin{array}{c}0.0053 \\
(<0.0001)\end{array}$ \\
\hline $\begin{array}{l}\text { Bad News* } \\
\text { Group }\end{array}$ & 1,583 & $\begin{array}{l}-0.0119 \\
-0.0059 \\
\end{array}$ & $\begin{array}{l}-0.0275 \\
-0.0161 \\
\end{array}$ & $\begin{array}{c}0.0156 \\
(0.0010) \\
\end{array}$ & $\begin{array}{c}0.0102 \\
(0.0005) \\
\end{array}$ \\
\hline
\end{tabular}

*Management forecast above prior year earnings are defined as good news, while those below prior year earnings number are defined as bad news.

** Variable definitions:

$\mathrm{CAR}_{\mathrm{it}}$ : Cumulative abnormal returns, which is the difference between the cumulative daily return and the size-decile-matched CRSP Value-Weighted Index return, over the window of the day (day=0) an earnings forecast is made and one day after the release $($ day $=+1)$, in year $\mathrm{t}$.

$\mathrm{FE}_{\mathrm{it}-1}$ : Prior-year forecast error, which is the difference between management earnings forecast and actual earnings per share, deflated by closing price one trading day before announcement of earnings forecast, in year $\mathrm{t}-1$.

\section{ACCURACY IN PRIOR EARNINGS FORECASTS}

This section is focused on investigating whether managers tend to be a certain type of forecaster; i.e., pessimistic or optimistic.

\section{Hypothesis Development}

A company might prefer to be pessimistic in its earnings forecast for several reasons. Mansour, Jouini, and Napp (2006) document a form of pessimism called pure-hazard introspective pessimism, which exists in individuals' beliefs. In a study that asks participants whether they will win in a coin-flipping game, they find that individuals have a higher judged probability for bad events. They further attribute such pessimism to defensive pessimism, as also discussed in Norem and Illingworth (1993). Defensive pessimism consists of "an anticipatory strategy that involves setting defensive low-expectations prior to entering a situation so as to defend against loss of self-esteem in the event of failure." (Mansour, Jouini, \& Napp, 2006). In the context of management earnings forecasts, it can be argued that managers would also exhibit such behavioral bias when contemplating earnings estimation numbers.

Avoiding negative earnings surprises might be another reason for pessimistic earnings forecasts. Management earnings forecast numbers could influence analysts' earnings expectations, which in turn could affect the magnitude of earnings surprises. By issuing a pessimistic earnings forecast, management could influence analysts' earnings expectations downward, therefore decreasing the possibility of negative earnings surprise.

A company might not only have had an incentive to be pessimistic in its earnings forecasts in prior periods, it might also be motivated to continue being pessimistic in the current period. Even if the prior earnings forecast turned out to be optimistic, management could be eager to alter such a reputation. Based on the findings above, market reaction to an announcement of management earnings forecasts with good news is more positive if management is viewed as pessimistic in its forecasts in the prior period. At the same time, the punishment from the stock market is less severe on the announcement of an earnings forecast with bad news if its prior earnings forecast was pessimistic. Based on that argument, the following hypotheses are stated in alternative forms: 
H2a: A manager who forecasts pessimistic earnings in a prior year will be more likely to be pessimistic in his earnings forecast in the current year.

H2b: A manager who forecasts optimistic earnings in a prior year will be more likely to be pessimistic in his earnings forecast in the current year.

\section{Empirical Results}

Table 3 presents results from Pearson chi-squared test. If several forecasts are made in a year, only the latest earnings forecast is included in the test on consistency in forecast accuracy. The results in Table 3 show that a firm tends to show a particular type of characteristic in its forecasts. If it has been pessimistic in its earnings forecast in the previous year, it continues to be so in the current year. Similarly, if a firm has issued an optimistic forecast in a prior year, it is not successful in changing its reputation to pessimism in the current year.

Table 3: Changes In Management Earnings Forecast Accuracy (Number Of Observations Is 8,544)

\begin{tabular}{|c|c|c|c|}
\hline & & \multicolumn{2}{|c|}{ Current Management Earnings Forecast $\left(\mathbf{F E}_{t}\right)$} \\
\hline & & Optimistic* & Pessimistic* \\
\hline \multirow{2}{*}{$\begin{array}{l}\text { Prior Management } \\
\text { Earnings Forecast } \\
\left(\text { FE }_{t-1}\right)\end{array}$} & Optimistic & $\begin{array}{c}2,532 \\
(29.63 \%)\end{array}$ & $\begin{array}{c}1,528 \\
(17.88 \%)\end{array}$ \\
\hline & Pessimistic & $\begin{array}{c}1,477 \\
(17.29 \%)\end{array}$ & $\begin{array}{c}3,007 \\
(35.19 \%)\end{array}$ \\
\hline
\end{tabular}

*An earnings forecast is optimistic if forecast error is positive and pessimistic if forecast error is negative.

FE: Forecast Error, which is the difference between management earnings forecast and actual earnings per share, deflated by closing price one trading day before the announcement of earnings forecast.

\section{MAINTAINING OR CHANGING REPUTATION: MANAGING EARNINGS UPWARDS}

This section investigates whether managers are motivated to manage earnings numbers towards maintaining the firm's reputation and fulfilling market expectations.

\section{Hypothesis Development}

Given the advantage of being pessimistic in earnings forecasts, managers with a pessimistic prior forecast might be motivated to continue being pessimistic while managers with an optimistic prior forecast might be motivated to change to pessimistic forecasts in the current year. One approach to this goal is to underestimate the earnings number in the event of an earnings forecast. However, after an earnings forecast is released and expectations are formed, unless a revised forecast is issued, management will work to manage the actual earnings number upwards in order to appear "pessimistic" in the current year.

Such a motivation could be even stronger for a company that experienced an optimistic forecast in the prior period. Managers with such a forecast have already been punished in the announcement of their earnings forecasts in the current period. Unless they change their reputation, they will be continually viewed as optimistic in their forecasts and this will further damage their credibility in future forecasts.

Therefore, the hypotheses are stated in alternative forms:

H3: Managers are more inclined to manage earnings upwards if they issued pessimistic or optimistic forecasts in the prior period.

H3a: The incentive to manage current earnings upwards is higher for managers with a reputation for optimistic prior forecast errors than for those with pessimistic prior forecast errors. 


\section{Variables Definition And Data Collection}

A firm could use two possible methods to manage earnings: through manipulation of total accruals or through real activities management. Two types of real activities investigated include manipulation of production cost and discretionary expenses. To test for management of earnings through total accruals and real activities, the methodology suggested by Roychowdhury (2006) was used. The definition of abnormal accruals was modified based on the suggestions from Kothari et al. (2005). The following cross-sectional regression was run to estimate normal total accruals, normal production costs, and normal discretionary expenses, for every industry and year:

$\frac{T A_{i t}}{\text { Asset }_{i t-1}}=\alpha_{0}+\alpha_{1} \frac{1}{\text { Asset }_{i t-1}}+\alpha_{2} \frac{\left(\Delta \text { Sales }_{i t}-\Delta A R_{i t}\right)}{\text { Asset }_{i t-1}}+\alpha_{3} \frac{P P E_{i t}}{\text { Asset }_{i t-1}}+\varepsilon_{t}$

where $\mathrm{TA}_{t}$ is total accrual in period $t$, which is calculated following Kothari et al. (2005). Sales is net sales while $\mathrm{AR}_{\mathrm{t}}$ is receivables from trading activities in period t. $\mathrm{PPE}_{t}$ is net property, plant and equipment in period t. $\mathrm{ROA}_{t}$ is defined as net income over total assets at the end of period t. All variables are deflated by total assets at the end of year $\mathrm{t}-1$.

$\frac{\text { PROD }_{i t}}{\text { Asset }_{i t-1}}=\alpha_{0}+\alpha_{1} \frac{1}{\text { Asset }_{i t-1}}+\alpha_{2} \frac{\text { Sales }_{i t}}{\text { Asset }_{i t-1}}+\alpha_{3} \frac{\Delta \text { Sales }_{i t}}{\text { Asset }_{i t-1}}+\alpha_{4} \frac{\Delta \text { Sales }_{i t-1}}{\text { Asset }_{i t-1}}+\varepsilon_{t}$

where $\mathrm{PROD}_{\mathrm{t}}=\mathrm{COGS}_{\mathrm{t}}+\Delta \mathrm{INV}_{\mathrm{t}} \cdot \Delta \mathrm{INV}_{\mathrm{t}}$ is change in inventory in period $\mathrm{t}$.

$\frac{\text { DISEXP }_{i t}}{\text { Asset }_{i t-1}}=\alpha_{0}+\alpha_{1} \frac{1}{\text { Asset }_{i t-1}}+\alpha_{2} \frac{\text { Sales }_{i t-1}}{\text { Asset }_{i t-1}}+\varepsilon_{t}$

where DISEXP $\mathrm{t}_{\mathrm{t}}$ is discretionary expenses in period t. Discretionary expenses include research and development expenses, advertising expenses, and sales and administrative expenses. The first two expenses are set to zero if the data was missing from the database described below.

Cross-sectional regression analysis was performed based on the industry classification from Fama and French (1997). Abnormal accruals, abnormal production costs, and abnormal discretionary expenses for a firm in a given year are the residual derived from regression results on equations (1), (2) and (3), respectively.

To test whether a firm manipulates earnings upwards given prior forecast error, the following regression was estimated:

$Y_{t}=\beta_{0}+\beta_{1} D S I Z E_{t-1}+\beta_{2} D M T B_{t-1}+\beta_{3} D R O A_{t}+\beta_{4} F E_{t-1}+\delta_{t}$

where the dependent variable, $\mathrm{Y}_{\mathrm{t}}$, is abnormal accruals, abnormal production costs, and abnormal discretionary expenses in three different estimations. $\mathrm{SIZE}_{\mathrm{t}-1}$ and $\mathrm{MTB}_{\mathrm{t}-1}$ are included to control for systematic variation in abnormal accruals, production costs, and discretionary expenses.

MTB $_{t-1}$ is the ratio of market value of equity to book value of equity at the end of period t-1, while SIZE is the logarithm of the market value of equity at the beginning of period t. To address the possibility of association between performance and abnormal values from estimation models (1), (2), and (3), net income, deflated by lagged total assets $\left(\mathrm{ROA}_{\mathrm{t}}\right)$ is also included in the regression. Since dependent variables are deviations from normal levels with an industry-year, these three control variables were included as their deviations from respective industry-year

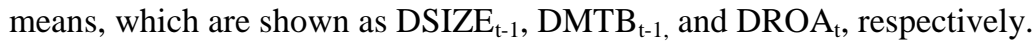

To control for the effect of different news within an earnings announcement, sample firm-years were classified into a good news group and a bad news group. An earnings announcement falls into the good news group if the actual earnings number is at least the median analyst forecast in the prior month. An earnings announcement is assigned to the bad news group if the actual earnings number is below the prior-month median analyst forecast. 
Given the models set up to test for hypothesis 3, if a firm manages its earnings through manipulation of abnormal accruals, abnormal production costs, and abnormal discretionary expenses, it is expected that $\mathrm{FE}_{\mathrm{t}-1}$ will be positively (negatively) associated with abnormal accruals and abnormal production costs in the cases with an optimistic (pessimistic) prior forecast. $\mathrm{FE}_{\mathrm{t}-1}$ is expected to be negatively (positively) associated with abnormal discretionary expenses in the cases with an optimistic (pessimistic) prior forecast.

Financial data needed to compute variables in the model were collected from the CRSP/Compustat Merged database. After requesting data availability to calculate variables, the final number of sample firm-years is 4,308, with 3,104 firm-years in the good news group and 1,204 firm-years in the bad news group. Out of 3,104 good-news firm-years, 1,594 issued a pessimistic forecast in the prior period while 1,510 issued an optimistic forecast in the prior period. Out of 1,204 bad-news firm-years, 660 had a prior pessimistic forecast while 544 had a prior optimistic forecast.

\section{Empirical Results}

Table 4 reports descriptive statistics of the whole sample and by groups with different news. Panel A shows that sample firm-years, on average, issued optimistic forecasts in the prior period. Panel B, on the other hand, shows that a firm-year with a pessimistic prior forecast is generally characterized with a bigger size, more total assets, and higher income before discontinued items than a firm-year with an optimistic prior forecast, regardless of the nature of the earnings news.

Table 4: Descriptive Statistic Of Variables In Earnings Management Test $($ Number Of Observations $=4,446)$ Panel A: Whole Sample Firms (Number Of Observations $=4,308$ )

\begin{tabular}{|l|c|c|c|c|c|}
\hline & Mean & Standard Deviation & Q1 & Median & Q3 \\
\hline SIZE $_{\mathrm{t}}$ (in millions) & 7951.55 & 23360.38 & 532.13 & 1502.44 & 5171.16 \\
\hline $\mathrm{MV} / \mathrm{BV}$ & 3.05 & 19.66 & 1.60 & 2.46 & 3.82 \\
\hline Total Assets (in millions) & 5711.42 & 14352.43 & 432.32 & 1308.96 & 3979.26 \\
\hline Sales (net) (in millions) & 6014.81 & 17860.64 & 478.21 & 1385.47 & 4438.38 \\
\hline $\mathrm{IB}_{\mathrm{t}}$ (in millions) & 379.23 & 1286.53 & 17.19 & 66.60 & 246.24 \\
\hline $\mathrm{FE}_{\mathrm{t}-1}$ & 0.0066 & 0.0196 & -0.0015 & 0.0000 & 0.0110 \\
\hline $\mathrm{TA}_{\mathrm{t}} /$ Asset $_{\mathrm{t}-1}$ & -0.0365 & 0.0703 & -0.0678 & -0.0365 & -0.0064 \\
\hline IB $_{\mathrm{t}}$ /Asset & 0.103 & 0.0334 & 0.0656 & 0.1063 \\
\hline PROD $_{\mathrm{t}-1}$ Asset & 0.0666 & 0.1003 & 0.3488 & 0.6656 & 1.1656 \\
\hline DISEXP $_{\mathrm{t}-\text { Asset }_{\mathrm{t}-1}}$ & 0.8797 & 0.7790 & 0.1823 & 0.3227 & 0.5191 \\
\hline
\end{tabular}

SIZE: Market value of equity, which is the multiple of common shares outstanding at the end of period $t$ and closing price at the end of period $\mathrm{t}$.

MV/BV: The ratio of market value of equity to book value of equity.

$\mathrm{IB}_{\mathrm{t}}$ : Income before extraordinary items at the end of period $\mathrm{t}$.

$\mathrm{FE}_{\mathrm{t}-1}$ : Prior-year forecast error, which is the difference between management earnings forecast and actual earnings per share, deflated by closing price one trading day before announcement of earnings forecast, in period $\mathrm{t}-1$.

$\mathrm{TA}_{\mathrm{t}} /$ Asset $_{\mathrm{t}-1}$ : Total accruals over lagged total assets, where total accruals $=$ changes in total current assets - changes in cash and short-term investments - changes in total current liabilities + changes in debt in current liabilities - depreciation and amortization.

PROD $_{\mathrm{t}} /$ Asset $_{\mathrm{t}-1}$ : Production cost over lagged total assets, where production cost is the sum of cost of goods sold and changes in inventory level.

DISEXP $_{\mathrm{t}} /$ Asset $_{\mathrm{t}-1}$ : Discretionary expenses over lagged total assets, where discretionary expenses includes research and development expenses, advertising expenses and selling and administrative expenses. 
Panel B: Sample Firms Within The Good News Group

And The Bad News Group, Respectively: Pessimistic Prior Forecast Error Versus Optimistic Prior Forecast Error

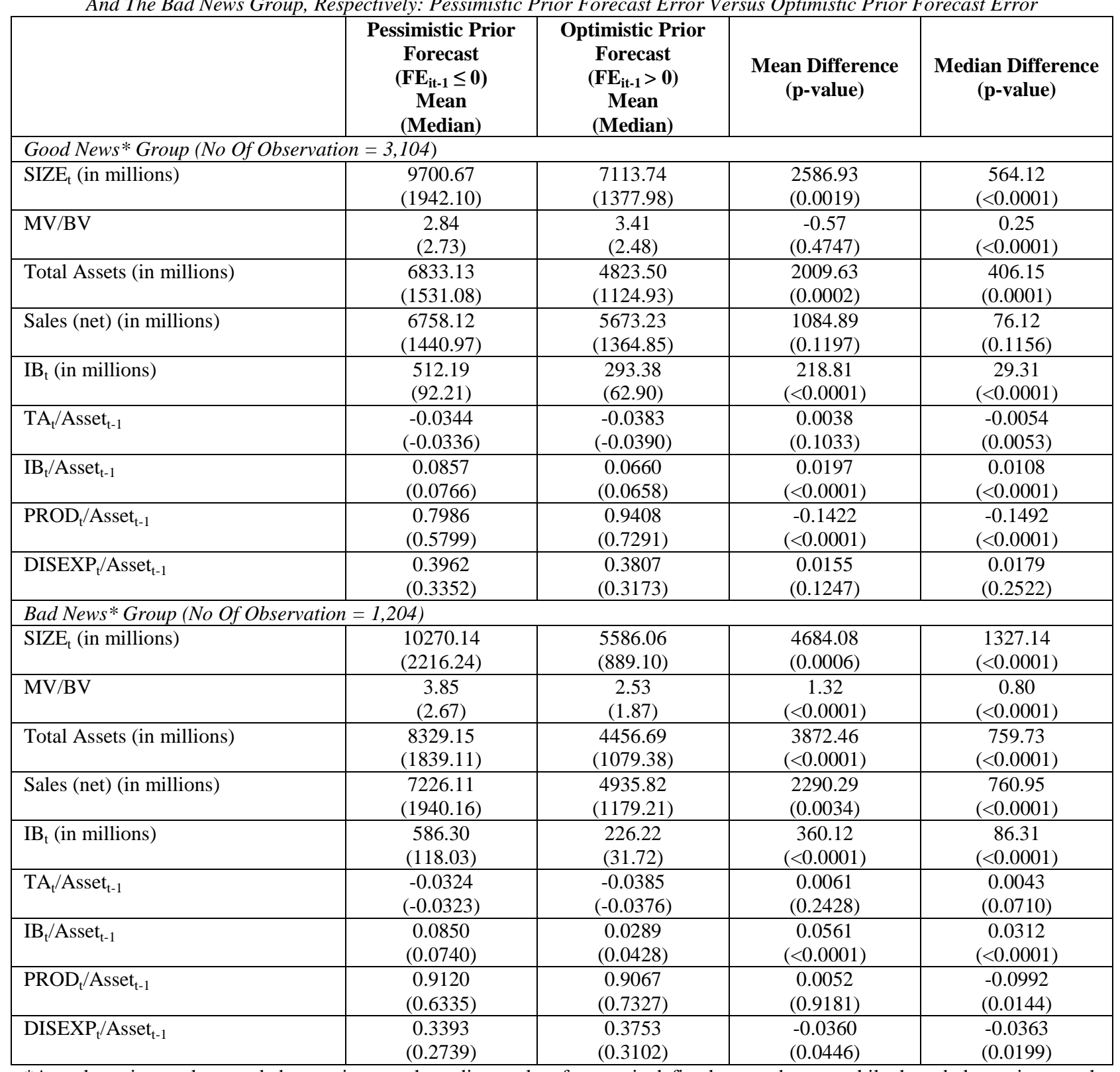

*Actual earnings at least and above prior-month median analyst forecast is defined as good news, while those below prior-month median analyst forecast is defined as bad news.

Variable definitions are as in Table 4 Panel A.

Table 5 reports Pearson correlation coefficients based on different earnings news and different forecast error in prior-period forecasts. Panel A provides evidence that if a firm issued a pessimistic forecast in the prior period, it could try to manage current earnings upwards by manipulating total accruals. On the other hand, Panel D indicates that a firm with an optimistic prior forecast could manipulate earnings through managing total accruals or production costs. 
Table 5: Correlation Tables

Panel A: Current Actual Earnings Convey Good News*: Firms With Prior Pessimistic Forecast

\begin{tabular}{|l|c|c|c|c|}
\hline & DSIZE $_{\mathbf{t}-\mathbf{1}}$ & $\mathbf{D M T B}_{\mathbf{t}-\mathbf{1}}$ & $\mathbf{R O A}_{\mathbf{t}}$ & \\
\hline DMTB $_{\mathrm{t}-1}$ & $\mathbf{0 . 0 8}$ & & & \\
\hline ROA $_{\mathrm{t}}$ & 0.04 & -0.05 & & \\
\hline FE $_{\mathrm{t}-1}$ & $\mathbf{0 . 1 9}$ & 0.03 & -0.01 & \\
\hline Abnormal Accruals & $\mathbf{- 0 . 0 8}$ & -0.02 & 0.01 & $-\mathbf{- 0 . 1 5}$ \\
\hline Abnormal PROD & -0.02 & $\mathbf{- 0 . 1 6}$ & -0.00 & -0.01 \\
\hline Abnormal DISEXP & $\mathbf{- 0 . 1 6}$ & $\mathbf{0 . 0 8}$ & 0.00 & $\mathbf{- 0 . 0 6}$ \\
\hline
\end{tabular}

This table reports Pearson correlation coefficient for 1,594 firm-years that convey good news in their current earnings with prior forecast being pessimistic over the period 1991-2010. Correlations significant at the 5\% level are marked in bold.

*Actual earnings at least and above prior-month median analyst forecast is defined as good news, while those below prior-month median analyst forecast is defined as bad news.

** Variable definitions:

DSIZE $_{\mathrm{t}-1}$ : Logarithm of the market value of equity at the end of period $\mathrm{t}-1$, expressed as deviations from the respective industrymean.

$\mathrm{DMTB}_{\mathrm{t}-1}$ : Market-to-book ratio at the end of period $\mathrm{t}-1$, expressed as deviations from the respective industry-mean.

$\mathrm{ROA}_{\mathrm{t}}$ : Income before extraordinary items at the end of period $t$, deflated by total assets at the end of period $t$.

$\mathrm{FE}_{\mathrm{t}-1}$ : Prior-year forecast error, which is the difference between management earnings forecast and actual earnings per share, deflated by closing price one trading day before announcement of earnings forecast, in period t- 1 .

\section{Panel B: Current Actual Earnings Convey Good News*: Firms With Prior Optimistic Forecast}

\begin{tabular}{|l|c|c|c|c|}
\hline & DSIZE $_{\mathbf{t}-\mathbf{1}}$ & $\mathbf{D M T B}_{\mathbf{t}-\mathbf{1}}$ & $\mathbf{R O A}_{\mathbf{t}}$ & $\mathbf{F E}_{\mathbf{t}-\mathbf{1}}$ \\
\hline $\mathrm{DMTB}_{\mathrm{t}-1}$ & $\mathbf{0 . 2 2}$ & & & \\
\hline $\mathrm{ROA}_{\mathrm{t}}$ & -0.05 & $\mathbf{- 0 . 1 4}$ & & \\
\hline $\mathrm{FE}_{\mathrm{t}-1}$ & $\mathbf{- 0 . 1 3}$ & -0.04 & 0.03 & \\
\hline Abnormal Accruals & -0.04 & -0.00 & -0.03 & -0.01 \\
\hline Abnormal PROD & -0.02 & $\mathbf{- 0 . 2 5}$ & 0.02 & 0.02 \\
\hline Abnormal DISEXP & $\mathbf{- 0 . 1 0}$ & $\mathbf{0 . 1 5}$ & -0.02 & 0.03 \\
\hline
\end{tabular}

This table reports Pearson correlation coefficient for 1,510 firm-years that convey good news in their current earnings with prior forecast being optimistic over the period 1991-2010. Correlations significant at the 5\% level are marked in bold.

Panel C: Current Actual Earnings Convey Bad News: Firms With Prior Pessimistic Forecast

\begin{tabular}{|l|c|c|c|c|}
\hline & DSIZE $_{\mathbf{t}-\mathbf{1}}$ & $\mathbf{D M T B}_{\mathbf{t}-\mathbf{1}}$ & $\mathbf{R O A}_{\mathbf{t}}$ & \\
\hline $\mathrm{DMTB}_{\mathrm{t}-1}$ & 0.07 & & & \\
\hline $\mathrm{ROA}_{\mathrm{t}}$ & -0.03 & -0.03 & & \\
\hline FE $_{\mathrm{t}-1}$ & $\mathbf{0 . 1 9}$ & 0.07 & -0.01 & \\
\hline Abnormal Accruals & -0.04 & 0.02 & -0.02 & -0.06 \\
\hline Abnormal PROD & 0.00 & $\mathbf{- 0 . 1 4}$ & 0.05 & 0.00 \\
\hline Abnormal DISEXP & $\mathbf{- 0 . 1 6}$ & $\mathbf{0 . 1 3}$ & 0.02 & -0.03 \\
\hline
\end{tabular}

This table reports Pearson correlation coefficient for 660 firm-years that convey bad news in their current earnings with prior forecast being pessimistic over the period 1991-2010. Correlations significant at the 5\% level are marked in bold.

Panel D: Current Actual Earnings Convey Bad News: Firms With Prior Optimistic Forecast

\begin{tabular}{|l|c|c|c|c|}
\hline & DSIZE $_{\mathbf{t}-\mathbf{1}}$ & $\mathbf{D M T B}_{\mathbf{t}-\mathbf{1}}$ & $\mathbf{R O A}_{\mathbf{t}}$ & \\
\hline DMTB $_{\mathrm{t}-1}$ & $\mathbf{0 . 1 6}$ & & & \\
\hline ROA $_{\mathrm{t}}$ & -0.06 & $\mathbf{- 0 . 0 9}$ & & \\
\hline FE $_{\mathrm{t}-1}$ & $\mathbf{- 0 . 1 8}$ & -0.02 & 0.03 & \\
\hline Abnormal Accruals & 0.01 & -0.03 & 0.03 & $\mathbf{0 . 0 9}$ \\
\hline Abnormal PROD & -0.08 & $\mathbf{- 0 . 1 2}$ & 0.05 & $\mathbf{0 . 1 0}$ \\
\hline Abnormal DISEXP & $\mathbf{- 0 . 1 2}$ & $\mathbf{0 . 1 1}$ & -0.04 & -0.05 \\
\hline
\end{tabular}

This table reports Pearson correlation coefficient for 544 firm-years that convey bad news in their current earnings with prior forecast being optimistic over the period 1991-2010. Correlations significant at the 5\% level are marked in bold.

Table 6 presents results from Ordinary Least Squared (OLS) regression analysis. T-statistics were calculated using standard error corrected for autocorrelation using the Newey-West procedure. Panels A, B, and C show results with different dependent variables, respectively: abnormal accruals, abnormal production costs, and abnormal discretionary expenses. Evidence shows that firms with an optimistic prior forecast have more incentive to 
change their reputations. They tend to manage earnings upwards by increasing total accruals, enhancing inventory levels (and thus increasing production costs), or lowering discretionary expenses.

Table 6: Ordinary Least Squared Regression Results

Panel A: Abnormal Accruals And Prior Forecast Error

\begin{tabular}{|c|c|c|c|c|c|}
\hline & Intercept & DSIZE $_{t-1}$ & DMTB $_{t-1}$ & $\mathbf{R O A}_{\mathbf{t}}$ & $\mathbf{F E}_{\mathrm{t}-1}$ \\
\hline \multicolumn{6}{|l|}{ Good News* Group } \\
\hline Pessimistic prior forecast $\left(\mathrm{FE}_{\mathrm{it}-1} \leq 0\right)$ & $\begin{array}{c}0.0032 \\
(0.61)\end{array}$ & $\begin{array}{c}-0.0132 \\
(-1.50)\end{array}$ & $\begin{array}{c}-0.0005 \\
(-0.98)\end{array}$ & $\begin{array}{c}0.0001 \\
(0.33)\end{array}$ & $\begin{array}{c}-1.0925 \\
(-1.23)\end{array}$ \\
\hline Optimistic Prior Forecast $\left(\mathrm{FE}_{\mathrm{it}-1}>0\right)$ & $\begin{array}{c}0.0020 \\
(0.69)\end{array}$ & $\begin{array}{c}-0.0081 \\
(-1.37)\end{array}$ & $\begin{array}{c}0.0001 \\
(0.08)\end{array}$ & $\begin{array}{c}-0.0001 \\
(-1.42)\end{array}$ & $\begin{array}{c}-0.0544 \\
(-0.70)\end{array}$ \\
\hline \multicolumn{6}{|l|}{ Bad News* Group } \\
\hline Pessimistic Prior Forecast $\left(\mathrm{FE}_{\mathrm{it}-1} \leq 0\right)$ & $\begin{array}{c}0.0049 \\
(1.07)\end{array}$ & $\begin{array}{c}-0.0090 \\
(-0.83)\end{array}$ & $\begin{array}{c}0.0011 \\
(0.57)\end{array}$ & $\begin{array}{c}-0.0001 \\
(-0.72)\end{array}$ & $\begin{array}{c}-0.5863 \\
(-1.25)\end{array}$ \\
\hline Optimistic Prior Forecast $\left(\mathrm{FE}_{\mathrm{it}-1}>0\right)$ & $\begin{array}{c}-0.0014 \\
(-0.30)\end{array}$ & $\begin{array}{c}0.0064 \\
(0.63)\end{array}$ & $\begin{array}{c}-0.0009 \\
(-0.62)\end{array}$ & $\begin{array}{c}0.0002 \\
(0.77)\end{array}$ & $\begin{array}{l}0.2269 \\
(2.11)^{\#}\end{array}$ \\
\hline
\end{tabular}

This table reports OLS regression results over a period of twenty years from 1991 to 2010 . The regressions being estimated are of the form: $Y_{t}=\beta_{0}+\beta_{1} D S I Z E_{t-1}+\beta_{2} D M T B_{t-1}+\beta_{3} D R O A_{t}+\beta_{4} F E_{t-1}+\delta_{t}$ where $\mathrm{Y}_{\mathrm{t}}$ is abnormal total accruals. Tstatistics are calculated with standard errors corrected for autocorrelation using the Newey-West procedure. They are reported in parentheses.

\# Significant at the $5 \%$ level.

*Actual earnings at least and above prior-month median analyst forecast are defined as good news, while those below priormonth median analyst forecast are defined as bad news.

** Variable definitions:

DSIZE $_{\mathrm{t}-1}$ : Logarithm of the market value of equity at the end of period $\mathrm{t}-1$, expressed as deviations from the respective industrymean.

DMTB $_{\mathrm{t}-1}$ : Market-to-book ratio at the end of period t-1, expressed as deviations from the respective industry-mean.

$\mathrm{ROA}_{\mathrm{t}}$ : Income before extraordinary items at the end of period $\mathrm{t}$, deflated by total assets at the end of period $\mathrm{t}$.

$\mathrm{FE}_{\mathrm{t}-1}$ : Prior-year forecast error, which is the difference between management earnings forecast and actual earnings per share, deflated by closing price one trading day before announcement of earnings forecast, in period t- 1 .

\begin{tabular}{|c|c|c|c|c|c|}
\hline \multicolumn{6}{|c|}{ nd Prion } \\
\hline & Intercept & DSIZE $_{t-1}$ & DMTB $_{\mathrm{t}-1}$ & $\mathbf{R O A}_{t}$ & $\mathbf{F E}_{\mathrm{t}-1}$ \\
\hline \multicolumn{6}{|l|}{ Good News* Group } \\
\hline Pessimistic Prior Forecast $\left(\mathrm{FE}_{\mathrm{it}-1} \leq 0\right)$ & $\begin{array}{l}-0.0291 \\
(-3.20)^{\#}\end{array}$ & $\begin{array}{c}-0.0041 \\
(-0.21)\end{array}$ & $\begin{array}{l}-0.0129 \\
(-2.13)^{\#}\end{array}$ & $\begin{array}{c}-0.0001 \\
(-0.69)\end{array}$ & $\begin{array}{c}-0.0549 \\
(-0.09)\end{array}$ \\
\hline Optimistic Prior Forecast $\left(\mathrm{FE}_{\mathrm{it}-1}>0\right)$ & $\begin{array}{l}-0.0452 \\
(-4.79)^{\#}\end{array}$ & $\begin{array}{c}0.0212 \\
(1.11)\end{array}$ & $\begin{array}{c}-0.0424 \\
(-5.67)\end{array}$ & $\begin{array}{c}0.0001 \\
(17.68)^{\#}\end{array}$ & $\begin{array}{c}0.0784 \\
(0.57)\end{array}$ \\
\hline \multicolumn{6}{|l|}{ Bad News* Group } \\
\hline Pessimistic Prior Forecast $\left(\mathrm{FE}_{\mathrm{it}-1} \leq 0\right)$ & $\begin{array}{c}-0.0078 \\
(-0.68)\end{array}$ & $\begin{array}{c}0.0078 \\
(0.30)\end{array}$ & $\begin{array}{c}-0.0184 \\
(-1.90)\end{array}$ & $\begin{array}{c}-0.0006 \\
(-0.82)\end{array}$ & $\begin{array}{c}0.1794 \\
(0.22)\end{array}$ \\
\hline Optimistic Prior Forecast $\left(\mathrm{FE}_{\mathrm{it}-1}>0\right)$ & $\begin{array}{c}-0.0025 \\
(-0.23)\end{array}$ & $\begin{array}{c}-0.0223 \\
(-0.94)\end{array}$ & $\begin{array}{c}-0.0094 \\
(-1.58)\end{array}$ & $\begin{array}{c}0.0005 \\
(1.13)\end{array}$ & $\begin{array}{l}0.5158 \\
(2.44)^{\#}\end{array}$ \\
\hline
\end{tabular}

This table reports OLS regression results over a period of twenty years from 1991 to 2010 . The regressions being estimated are of the form: $Y_{t}=\beta_{0}+\beta_{1} D S I Z E_{t-1}+\beta_{2} D M T B_{t-1}+\beta_{3} D R O A_{t}+\beta_{4} F E_{t-1}+\delta_{t}$ where $\mathrm{Y}_{\mathrm{t}}$ is abnormal production cost. Tstatistics are calculated with standard errors corrected for autocorrelation using the Newey-West procedure. They are reported in parentheses.

\# Significant at the $5 \%$ level.

*Actual earnings at least and above prior-month median analyst forecast are defined as good news, while those below priormonth median analyst forecast are defined as bad news.

Variable definitions are as in Table 6 Panel A. 
Panel C: Abnormal discretionary expense and prior forecast error

\begin{tabular}{|c|c|c|c|c|c|}
\hline & Intercept & DSIZE $_{t-1}$ & DMTB $_{t-1}$ & $\mathbf{R O A}_{t}$ & $\mathbf{F E}_{\mathrm{t}-1}$ \\
\hline \multicolumn{6}{|l|}{ Good News* Group } \\
\hline Pessimistic Prior Forecast $\left(\mathrm{FE}_{\mathrm{it}-1} \leq 0\right)$ & $\begin{array}{c}0.0194 \\
(1.72) \\
\end{array}$ & $\begin{array}{l}-0.1408 \\
(-6.11)^{\#} \\
\end{array}$ & $\begin{array}{c}0.0099 \\
(1.76) \\
\end{array}$ & $\begin{array}{l}-0.0001 \\
(-2.92)^{\#}\end{array}$ & $\begin{array}{c}-0.8432 \\
(-0.97) \\
\end{array}$ \\
\hline Optimistic Prior Forecast $\left(\mathrm{FE}_{\mathrm{it}-1}>0\right)$ & $\begin{array}{l}0.0177 \\
(1.50) \\
\end{array}$ & $\begin{array}{l}-0.1090 \\
(-4.62)^{\#}\end{array}$ & $\begin{array}{l}0.0359 \\
(4.32)^{\#}\end{array}$ & $\begin{array}{l}-0.0001 \\
(-8.41)^{\#}\end{array}$ & $\begin{array}{c}0.2033 \\
(1.36) \\
\end{array}$ \\
\hline \multicolumn{6}{|l|}{ Bad News* Group } \\
\hline Pessimistic Prior Forecast $\left(\mathrm{FE}_{\mathrm{it}-1} \leq 0\right)$ & $\begin{array}{c}0.0079 \\
(0.52) \\
\end{array}$ & $\begin{array}{l}-0.1397 \\
(-4.32)^{\#}\end{array}$ & $\begin{array}{l}0.0240 \\
(2.03)^{\#}\end{array}$ & $\begin{array}{c}0.0002 \\
(0.22) \\
\end{array}$ & $\begin{array}{c}-0.1270 \\
(-0.12)\end{array}$ \\
\hline Optimistic Prior Forecast $\left(\mathrm{FE}_{\mathrm{it}-1}>0\right)$ & $\begin{array}{c}0.0093 \\
(0.71) \\
\end{array}$ & $\begin{array}{l}-0.1041 \\
(-3.62)^{\#}\end{array}$ & $\begin{array}{l}0.0131 \\
(2.09)^{\#}\end{array}$ & $\begin{array}{c}-0.0005 \\
(-1.17) \\
\end{array}$ & $\begin{array}{l}-0.5415 \\
(-2.36)^{\#}\end{array}$ \\
\hline
\end{tabular}

This table reports OLS regression results over a period of twenty years from 1991 to 2010 . The regressions being estimated are of the form: $Y_{t}=\beta_{0}+\beta_{1} D S I Z E_{t-1}+\beta_{2} D M T B_{t-1}+\beta_{3} D R O A_{t}+\beta_{4} F E_{t-1}+\delta_{t}$ where $\mathrm{Y}_{\mathrm{t}}$ is abnormal discretionary expenses. T-statistics are calculated with standard errors corrected for autocorrelation using the Newey-West procedure. They are reported in parentheses.

\# Significant at the $5 \%$ level.

*Actual earnings at least and above prior-month median analyst forecast are defined as good news, while those below priormonth median analyst forecast are defined as bad news.

Variable definitions are as in Table 6 Panel A.

\section{CONCLUSION}

This paper aims to answer three questions: 1) Is market reaction to current earnings management forecasts fixed on previous forecast error?, 2) Does a firm try to maintain or change its reputation for forecasting (optimistic or pessimistic)?, and 3) Does a firm manage its earnings through total accruals or real activities in order to maintain or change its reputation?

Based on t-tests and Wilcoxon rank-signed tests, it was found that the market reacts more positively to good news when a prior forecast was pessimistic and more negatively to bad news when a prior forecast was optimistic. It was also found that a firm tends to maintain its reputation for being pessimistic in its forecasts, but does not seem to change its reputation for being optimistic in its forecasts. Finally, there was evidence that a firm is motivated to manage its earnings through manipulating total accruals, accumulating inventory levels, or reducing discretionary expenses if it issued an optimistic forecast in the prior period. Overall, the findings indicate that a firm with optimistic prior forecasts is more likely to manage its current earnings upwards. However, its efforts might be inadequate because the results show that it is more likely to remain optimistic in its forecasts.

\section{AUTHOR INFORMATION}

Dr. Jing-Wen Yang received the Ph.D. degrees in Accounting from the University of Maryland, College Park, U.S.A. She is currently an assistant professor at College of Business and Economics at California State University East Bay. Her research interests are in voluntary disclosure behavior, competition and accounting education. E-mail: jingwen.yang@csueastbay.edu

\section{REFERENCES}

1. Baik, B., Jiang, G. (2006). The Use of management forecast to dampen analysts' expectations. Journal of Accounting and Public Policy 25(5): 531-553.

2. $\quad$ Fama, E., French, K. (1997). Industry costs of equity. Journal of Financial Economics 43(2): 153-193.

3. Hirst, D. E., Koonce, L., Miller, J. (1999). The Joint effect of management's prior forecast accuracy and the form of its financial forecasts on investor judgment. Journal of Accounting Research 37(Suppl.): 101-124.

4. Kasznik, R. (1999). On the association between voluntary disclosure and earnings management. Journal of Accounting Research 37(1): 57-81.

5. Kothari, S. P., Leone, A. J., Wasley, C. E. (2005). Performance matched discretionary accrual measures. Journal of Accounting and Economics 39(1): 163-197. 
6. Lobo, G. J., Zhou, J. (2001). Disclosure quality and earnings management. Working paper, Syracuse University.

7. Mansour, S. B., Jouini, E., Napp, C. (2006). Is there a "pessimistic" bias in individual beliefs? Evidence from a simple survey. Theory and Decision 61(4): 345-362.

8. Norem, J. K., Illingworth, K.S. S. (1993). Strategy-dependent effects of reflecting on self and tasks: Some implications of optimism and defensive pessimism. Journal of Personality and Social Psychology 65(4): 822-835.

9. $\quad$ Rogers, J. L., Stocken, P. C. (2005). Credibility of management forecasts. The Accounting Review 80(4): 1233-1260.

10. Roychowdhury, S. (2006). Earnings management through real activities manipulation. Journal of Accounting and Economics 42(3): 335-370.

11. Soffer, L. C., Thigarajan, S. R., Walther, B. (2000). Earnings preannouncement strategies. Review of Accounting Studies 5(1): 5-26.

12. Waymire, G. (1984). Additional evidence on the information content of management earnings forecasts. Journal of Accounting Research 22(2): 703-718.

13. Williams, P. A. (1996). The Relation between a prior earnings forecast by management and analyst response to a current management forecast. The Accounting Review 71(1): 103-113. 